\title{
Research on the Cognition of College Students on Anti-terrorism in Colleges and Universities in the New Period and Its Countermeasures
}

\author{
Taking Liuzhou Area as an Example*
}

\author{
Qianwei Jin \\ School of Arts and Cultural Communication \\ Guangxi University of Science and Technology \\ Liuzhou, China 545006
}

\author{
Yuemin $\mathrm{Li}$ \\ School of Arts and Cultural Communication \\ Guangxi University of Science and Technology \\ Liuzhou, China 545006
}

\begin{abstract}
In the new era, China has entered the critical period of "two-hundred-year" construction. Under this background, it is of great practical significance to study antiterrorism in colleges and universities. This topic takes the Liuzhou area as an example. Through research, it clearly understands the status quo of anti-terrorism in colleges and universities, and analyzes existing problems. At the same time, it provides suggestions for resolving related issues. Antiterrorism education enters the classroom and the mind. It would enhance the ability of teachers and students to fight against terrorism. It should strengthen detail management and implement accountability mechanisms. It is hoped that this study will provide intellectual support for the realization of safe campus, learning campus, and cultural campus.
\end{abstract}

Keywords-new era; anti-terrorism in universities; investigation; countermeasures

\section{INTRODUCTION}

The Nineteenth National Congress of the Communist Party of China marked the beginning of a new period of socialist construction with distinctive characteristics. Colleges and universities are responsible for providing talent support for the Chinese dream of realizing the great rejuvenation of the Chinese nation at an early date. Therefore, building safe campus, learning campus and cultural campus can help the cultivation of outstanding talents. The college students are aware of possible terrorist issues. We hope to use this as a cut-in point for discussion. According to field research, we can clarify the relevant factors that cause terrorist incidents in colleges and universities and provide effective countermeasures for anti-terrorism in universities.

This topic takes the example of colleges and universities in Liuzhou of Guangxi province as an example to explore anti-terrorism education. Liuzhou is located in the northern part of Guangxi province. As the industrial town and

*Fund Project: Research Project on the Safety and Stability of Guangxi Education System Maintenance in 2016: "A Survey of the Recognition of College Students on the Anti-terrorist Issues in Colleges and Universities and Countermeasures in the New Era-Taking Liuzhou Area as an Example" (No. 20161B026) ecological city in Guizhong province, it has 2 undergraduate and 5 colleges and universities, and has nearly 50,000 college students. In order to investigate the anti-terrorism problems in colleges and universities in the new era, the research group developed a research plan. From June 2016 to June 2017, 500 questionnaires were distributed, 496 were retrieved, 492 were valid, and the efficiency was as high as $98 \%$. Several college teachers and students strived to fully understand the various problems. And then, they summarize the effective anti-terrorism strategies.

\section{STATUS SURVEY}

The research group has developed a feasible research program. Through questionnaires, the author visits teachers and students in colleges and universities to collect relevant information. According to the material analysis summarized in September 2017, it is believed that college teachers and students have a clear understanding of possible terrorist incidents. And they generally agree that it is necessary to take effective measures to ensure campus safety. And they actively provide feasible countermeasures and suggestions.

\section{A. They Are Clear about the Possible Terrorist Factors in Colleges and Universities}

First are foreign factors. China's reform and opening up has created remarkable achievements. There are some hostile men who are unwilling to develop China better. They may take hostile actions and take risks to create terrorist incidents and destroy the stability and unity of China. Although the intention to hinder the rapid development of China is not necessarily achieved, it is still possible to spread unfavorable factors by creating a focus of terror. College students are active young people. They have the sense of innovation and challenging spirit. They dare to do it. At the same time, they have rebelliousness. In addition, their social experience is not rich enough. They are easy to be the targets for the development or invasion of terrorists. Colleges and universities are involved in society and schools, parents and other personnel. Once a terrorist incident has become a social focus, it has a sensational effect. Second is its factors. There 
are many teachers and students in colleges and universities, which generally adopt open management. School gates, teaching places, and student dormitories are basically free to enter and exit. There are loopholes in the management of entry and exit. The safety equipment such as firefighting is generally complete, and the targeted training and use have not kept pace. In other words, most teachers and students cannot use the safety equipment skillfully. College students are generally adults and have the ability to manage selfcontrol. However, they have not been fully mature. Individuals who are extremely fragile, encounter certain difficulties in life, or are treated unfairly, and may lose their senses or take extreme measures such as the release of inner repression by attacks, revenge, etc.

\section{B. We Are Wary of the Connection between Internet Applications and Terrorist Incidents}

First, the advantages of smartphones are easy to make communication. Of course, they will be used as tools for terrorists. Undergraduates have acquired a certain level of knowledge and skills. It can be said that they would like all kinds of technology-based tools at that age. Each man has a smart phone. And they can search on the Internet. This will not only facilitate the search for various learning materials, but also enable timely communication with the outside world. However, there is also a certain degree of hidden concern. Individual terrorists may eye college students, use their pure enthusiasm, and induce them to do bad things. Second, game violence factors may generate links to the real society. And virtual pure games become the realistic violent terror. In the survey, most students believe that they can distinguish the games and reality. They wouldn't equate the reality with bloody and violent games. And they wouldn't take violence in the real world. Also, they wouldn't damage the beautiful and warm campus environment. Thirdly, terrorist incidents may arise from online exchanges. The Internet and terrorist activities cannot be ignored. Although smartphones are commonly used, there may be the possibility that immersive games may be used by criminals. However, most students think that they can cope with them. However, according to the actual investigation, adolescent college students are easily used by online fraudsters with their imagination and longing for good love. Almost all of them can be heard to be defrauded or even deceived in the survey. Although the victim population has not spread, it still needs to be vigilant that the victim cannot control his personal emotions. And he may also use extreme methods to create terrorist incidents.

\section{Colleges and Universities Have Caused a Great Deal of Attention to Terrorist Activities}

There are many teachers and students in colleges and universities, which are usually around 20,000 people. In case of unexpected events, it may cause irreversible situation. First, large-scale power outages in the evening may cause stampede. Second, rumors such as earthquakes may cause a tragedy. Third, driving too fast in the campus would cause casualties. Fourth, food and beverage deterioration may cause the poisoning. Fifth, there are incidents of death caused by the aging of swimming baths and other equipment. There are other possible victimization factors. Through investigation, it is found that various schools have more or less similar incidents. The lessons are often profound and the price paid is very high. In the past, people forgot about it. Therefore, schools need to take it seriously. According to surveys, most of the schools' shops are outsourced to social workers. And it is sufficient to sign safety, use, and management contracts. The main responsibility lies with the contractor. The school does not have so many responsibilities. Many schools have no this idea. Or less, this will result in the loss of school management responsibilities. They don't take effective measures to increase management, especially for food and beverages. And they neglect the management. Individual shop owners often obtain more profits with the shoddy. They would sell the goods that are not of high quality. The students are busy with classes in the morning. They usually buy food on the roadside and go to class. This may cause poisoning to many people and become the focus of social concern. Through vigorous publicity and education in recent years, colleges and universities have generally strengthened their management measures and paid more attention to terrorist activities caused by their intension.

\section{EXISTING PROBLEMS}

Liuzhou is a historical and cultural city. To contact history will be associated with Liu Zongyuan. This land is deeply influenced by the Central Plains culture. In addition, Guangxi has always paid attention to the unity and harmony of ethnic relations, and people learn to live here. Employment is very comfortable. The research group is fully aware of this very favorable social background. Also, it is believed that there is still a hidden danger in the peaceful environment where the song and dance is rising. Based on anti-terrorism from the perspective of national security, the problems that may exist in colleges and universities are analyzed.

\section{A. The Study of Anti-terrorism Issues in the New Era Needs to Be Strengthened}

First, the party and the government pay special attention to national security education in the new period. In the middle of the 21st century, as an important node for realizing the great rejuvenation of the Chinese dream of the Chinese nation, it is necessary to organize all Chinese people to work together in a concerted manner and to make advancement solidly. In order to ensure the smooth progress of the Chinese nation's great cause, people on the front line should work together. After the accumulation of the 40th anniversary of reform and opening up, China's overall national strength has become more powerful. At the same time, it has also caused repression of other countries. And it would lead to unpredictable disruption. Therefore, the party and the government lost no time in adopting legal systems such as national security, cyber security, and anti-terrorism. This is to ensure smooth protection for "two-hundred-year" construction. Understanding the anti-terrorism education carried out by colleges and universities in this context have more practical significance. Second, the research group believes that anti-terrorism education is not only about selfprotection, but also rises to the height of national security. 
The possible terrorist incidents are not singular. According to the investigation, many students think that they must be prepared for terrorist incidents. And they do not realize that it is related to the whole national security. The good national unity, security and stable social situation in Guangxi also caused many teachers and students to relax their vigilance. Even for the terrorist incidents that took place, they believed that they were only case-specific and had no special attention. They also did not take effective measures to prevent the next time. Third, colleges and universities do not make good use of existing good facilities and teaching and scientific research conditions. And they don't use human and material resources in universities to strengthen research. Otherwise, they would provide theoretical support for anti-terrorism education. And then, they would provide effective practical programs, and further provide supporting research and development products for anti-terrorism.

\section{B. There Is Not Enough Attention to Possible Terrorist Incidents}

According to research statistics of the research group, university teachers and students generally think that the society is very safe now. And there will be no terrorist incident. This recognition rate is as high as $73.4 \%$. In this regard, the call for strengthening anti-terrorism education is necessary. In the following, we would describe the possibility of a terrorist attack. Firstly, students from Liuzhou Area belong to transprovincial enrollment. And they come from many provinces across the country. Parents in other places generally think that Liuzhou is a heavy industrial area and has a high status in Guangxi. They do not realize that Guangxi, where Liuzhou is located, is located in the frontier of the motherland, making entry and exit more convenient and hostile. The molecules are easy to get in and out. Secondly, in order to increase international popularity, Liuzhou actively promotes urban charm. The annual international water sports attract athletes and tourists from all over the world. At the same time, they attract the attention of the world. In order to increase the publicity effect of the event, they would organize teachers and students to participate in arts and cultural propaganda marches each time, as well as song and dance performances, etc. If there are terrorist attacks, it would have big impact. And they must pay sufficient attention to possible terrorist activities. Thirdly, Liuzhou is an important industrial base for new China planning and construction. Through more than 60 years of development, it has formed a relatively complete industrial system. In order to enhance its business and technical capabilities, experts from South Korea, Japan, and Germany joined relevant business entities. They have made contribution to the development of Liuzhou. It is also inevitable that those with ulterior motives will use job opportunities to infiltrate colleges and seek opportunistic attacks to trigger terrorist incidents. Therefore, to stand above this hot land of Liuzhou, it is necessary to increase vigilance and take effective actions to maintain a stable and safe social environment.

\section{Teachers and Students Need to Step up Their Efforts to Counter Terrorism}

The research team believes that teachers and students in colleges and universities do not have sufficient anti-terrorism capabilities. The social development in the new period is more and more in line with the wish of most people, and most people feel more and more happy. In particular, since the party's 18th National Congress, the state has taken significant scientific and efficient measures. Social management has been in place. Teachers and students of universities have been wary. Apart from these, colleges and universities still have problems. First, teachers and students think that the main task is learning. According to the national plan, using various means is to ensure the continuous progress of teaching and scientific research work. And there is no problem. However, it cannot be considered that colleges and universities are a paradise of song and dance. Some terrorists or individual teachers and students may have psychological imbalances. And they may make unpredictable terrorist incidents. It is possible. Second, university teachers are mainly engaged in teaching and research. Students are busy with textual research and employment. They generally do not pay attention to matters that are not related to them. The research group found that this understanding is widespread. College teachers and students have high academic qualifications and high quality. And they generally don't interfere in other people's activities. They would respect others outside. Thus, it would lay a crisis for possible terrorist incidents. Thirdly, most domestic universities, including the colleges in Liuzhou, believe that the terrorist attacks are terrible. However, the probability is low. They usually do not have much exercise to temper their counterterrorism abilities. They often don't take serious training. When encountering a terrorist event, they can't deal with them. And it may cause a lot of casualties.

\section{COUNTERMEASURES AND SUGGESTIONS}

In the 21 st century, China is full of vitality for development and innovation. Under the strong leadership of the party and the government, it is from being wealthy to being strong and advancing. The Chinese Dream of "two hundred years" construction is guiding the 1.3 billion Chinese people to the center of world stage. This research aims at the investigation of anti-terrorism in colleges and universities in Liuzhou Area. It is based on the great mission of fulfilling the Chinese dream in the new era. It aims to build safe schools, learning schools, and cultural schools to cultivate more outstanding talents. And then, they can find anti-terrorism problem. Through the efforts, they would find the solutions. "They should coordinate the functions of the ideology, organization, institution, management, equipment, and drills". [1] And then, they would deal with possible terrorist incidents. Then, it would provide a reference for building a safe and stable university campus.

\section{A. Anti-terrorism Education would Enter into the Classroom and the Mind}

Anti-terrorism education in colleges and universities needs to be strengthened urgently. In order to have a campus 
full of laughter, it is necessary to have hidden consciousness and solid actions. Anti-terrorism education enters the classroom and the mind. First, the classroom would be a main education position to actively carry out anti-terrorism education. Combining anti-terrorism education based on different disciplines, the colleges and universities should arrange natural and harmonious content. It shouldn't give the students a sense of indoctrination. This is to adopt teaching method that conforms to modern teaching concepts. And it would guide students to value anti-terrorism education. Second, anti-terrorist education is in the brain. In addition to classroom teaching, we must use campus facilities. We can use various bulletin boards, post various anti-terrorism education pictures, strengthen anti-terrorism awareness, and carry out special events on the national security education day, distribute brochures, organize students to carry out cultural and artistic activities to attract more students' attention. And the colleges and universities should invite professionals such as the Public Prosecution Law to carry out special training, and invite experts to give lectures to strengthen the anti-terrorism awareness of teachers and students. Third, the colleges and universities should strengthen scientific research and carry out scientific research on effective counter-terrorism education. The education department provides research and planning for the project and supports a certain amount of funds to facilitate the smooth development of related work for teachers and students. At the same time, colleges and universities use the innovation and entrepreneurship training to dock with the anti-terrorism education. It would guide students to consciously incorporate anti-terrorism into the perspective of research. If it can naturally connect with the topic of the dissertation, it is also a good method. Combining literary and history majors, it would explore different works and antiterrorism issues in different eras.

\section{B. To Improve Teacher-student Anti-terrorism Capabilities}

Teachers and students in colleges and universities pay more attention to study and improvement. They often use reading training as an important task, and they do not pay much attention to things beyond this. If terrorist incidents occur, they may be at a loss. Therefore, effective measures must be taken to improve the anti-terrorism capabilities of teachers and students. First, through professional guidance and training, we must effectively improve anti-terrorism capabilities. The colleges and universities should know the general terrorist incidents. Also, they should understand how to respond to different situations, and what methods can be effective. These problems require professional training and learning. And then, it would strengthen the anti-terrorism skill of teachers and students. And it would enhance the antiterrorism capabilities of teachers and students in repeated exercises. Second, the schools have various specialties, including school doctors and affiliated hospitals, all of whom have salvage guidance doctors. Therefore, it is necessary to integrate all forces to implement cross-professional cooperation training, guide teachers and students to master relevant self-rescue and rescue methods. And it would complete emergency rescue work in a short time. Third, the colleges and universities should strengthen the contract with society. Through fire drills, public security and other collaborative drills, different projects should be exercised in different occasions and different times. At the same time, it should carry out school sports events, song and dance evenings and other large-scale activities to consciously strengthen training. Teachers and students can master evacuation and rescue operations. Third, the colleges and universities should establish a reward mechanism for antiterrorism education. In order to better create a sense of security in colleges and universities, it should create a safe campus, study campus, and cultural campus. The school functional departments must incorporate anti-terrorism into the scope of teaching, scientific research, and extracurricular practice. Based on student dormitories and student societies, it should create a new mechanism for student education and management. [2] It should give priority to those who have achieved outstanding results in the anti-terrorism project in teaching and research. And it also should give priority to those who guide students to strengthen anti-terrorism training in extracurricular activities in the evaluation. And the colleges and universities should provide more opportunities to attract more teachers and students temper their anti-terrorism capabilities. And this would lay a solid foundation for building a harmonious and safe university campus suitable for learning.

\section{To Strengthen Detail Management and Implement Accountability Mechanisms}

In the history of China, we have advocated peace and humanity as our salient features. We have made great progress in all aspects of reform and opening up. And people's ideas for the progress of civilization have been continuously improved. The friendship between everyone and $m e$ is strengthened. The comprehensive quality of teachers and students in colleges and universities is relatively high. The tranquility and warmth of university campuses are suitable for learning and enterprising. It can be said that China's security issues including universities and colleges are not really big problems. In other words, China's 9.6 million square kilometers are very safe. However, the research group still proposes to take preventive measures and pay attention to detail management to block all kinds of possible loopholes. The first is to strengthen the management of school entrances and exits. There are many teachers and students in colleges and universities. And it is hoped that the school badge will be used as a sign to strengthen the registration system for foreigners. The second is to strengthen campus police patrolling, implement the system responsible for filming, strengthen the time and place supervision accountability mechanism, especially in the morning a large number of students attending classes, eating, returning to the dormitory at noon, as well as evening snoring, etc. We must strengthen the police patrolling. And we should ensure that every part of the campus is under control. Third, it should strengthen the teacher and attendance management system. The university classroom should take the flow management. They will change the classroom in each semester. The large class is very common. And the teacher cannot identify each student. The teachers should strengthen attendance, and timely understand the 
status of students' attendance. Although there are generally 8 or 6 people in the student dormitories, the number of students is relatively small. However, the number of students living in the school is relatively large. And the number of dormitory management personnel is not large. Even so, it is necessary to strengthen management. And inspection should be stepped up at night. It should prevent security problems.

\section{CONCLUSION}

Anti-terrorism in colleges and universities belongs to the category of national security education. Through investigation, the problems discovered are explored to promote the study of anti-terrorism issues in universities. The purpose is to build a harmonious, peaceful and comfortable campus environment. In peaceful environment, the students can learn well. And then, the study can be done well. It would improve cultural heritage and achieve longterm stability. The new period is the key period for practicing the "two-hundred-year" construction. It guides teachers and students to take a comprehensive view of the anti-terrorism problems existing in colleges and universities. Anti-terrorism education would enter into the classroom. And the anti-terrorism abilities of teachers and students are enhanced. The detailed management is strengthened. Teachers and students work together to create the university environment of singing and laughing. It would make contributions to cultivating more outstanding talents that will promote the Chinese nation's great rejuvenation of the Chinese dream.

\section{REFERENCES}

[1] Wang Qinghua, Gong Kai. An investigation and analysis of college students' understanding of anti-terrorist issues in colleges and universities [J]. Journal of North China Electric Power University (Social Sciences), 2010(2). 汪庆华, 宫凯. 关于大学生对高校反恐 问题认识的调查分析 [J]. 华北电力大学学报 (社科版) , 2010 (2)

[2] Dai Shugen. On the construction of people-oriented ideological and political education system for college students[J]. Journal of Hunan University of Science and Technology, 2004(11). 戴树根. 论以人为 本的大学生思想政治教育体系的构建 [J]. 湖南科技大学学报, 2004 (11). 